Revta brasil. Bot., São Paulo, V.24, n.1, p.35-41, mar. 2001

\title{
Effects of moisture content and temperature during storage on germination of the achenes of Bidens gardneri Baker
}

\author{
JOSIMARA N. RONDON ${ }^{1}$, REGINA M. SASSAKI ${ }^{1}$, LILIAN B.P. ZAIDAN ${ }^{1,2}$ \\ and G.M. FELIPPE ${ }^{1,2}$
}

(received: December 8, 1999; accepted: September 26, 2000)

\begin{abstract}
Effects of moisture content and temperature during storage on germination of the achenes of Bidens gardneri Baker). Bidens gardneri is a herbaceous species of the cerrados, whose seeds are light sensitive at $25{ }^{\circ} \mathrm{C}$, but they become indifferent to light when stored in soil. In this work the effects of moisture content, temperature and light (during storage) upon light sensitivity during germination were studied. Ripe achenes were collected in the cerrados of Itirapina and Moji Guaçu, State of São Paulo, Brazil. The storage conditions of the achenes varied in each experiment. Achenes were stored in darkness or light, in closed bottles, at $4{ }^{\circ} \mathrm{C}, 20 / 30^{\circ} \mathrm{C}$ or $25^{\circ} \mathrm{C}$. Achenes were imbibed for $24 \mathrm{~h}$ at $4{ }^{\circ} \mathrm{C}, 25^{\circ} \mathrm{C}$ or $20 / 30^{\circ} \mathrm{C}$ (in darkness) and then stored for $1,10,20,30$ and 40 days $(40$ days only for $4{ }^{\circ} \mathrm{C}$ and $25^{\circ} \mathrm{C}$ ). Germination tests were conducted at $25^{\circ} \mathrm{C}$ and $20 / 30^{\circ} \mathrm{C}$. The achenes not previously imbibed showed sensitivity to light during germination. High moisture content did not affect light sensitivity of the achenes during germination but high moisture content together with storage temperatures of $25^{\circ} \mathrm{C}$ and $20 / 30^{\circ} \mathrm{C}$ had a deleterious effect upon the longevity of the achenes. Alternate temperatures during germination did not change the light sensitivity of newly collected achenes from Itirapina but changed the light sensitivity of the achenes stored imbibed at $4{ }^{\circ} \mathrm{C}$ in darkness. Alternate temperatures during storage of achenes with low moisture content did not change their photoblastism when germination was carried out at $25^{\circ} \mathrm{C}$. Alternate temperatures during storage of achenes with high moisture content followed by alternate temperatures during germination changed the light sensitivity of the achenes.
\end{abstract}

RESUMO - (Efeito do conteúdo de água e temperatura durante o armazenamento na germinação dos aquênios de Bidens gardneri Baker). Bidens gardneri é uma espécie herbácea dos cerrados, cujas sementes são fotoblásticas positivas a $25{ }^{\circ} \mathrm{C}$, mas tornam-se indiferentes à luz quando armazenadas em solo. Neste trabalho, foram estudados os efeitos do conteúdo de água dos aquênios, da temperatura e da luz (durante o armazenamento) na sensibilidade à luz durante a germinação. Os aquênios foram coletados nos cerrados de Itirapina e de Moji Guaçu, estado de São Paulo, Brasil. As condições de armazenamento variaram em cada experimento. Os aquênios foram armazenados no escuro ou em luz, em vidros fechados a $4{ }^{\circ} \mathrm{C}, 25^{\circ} \mathrm{C}$ e $20 / 30{ }^{\circ} \mathrm{C}$. Os aquênios foram embebidos por 24 horas a $4{ }^{\circ} \mathrm{C}, 25^{\circ} \mathrm{C}$ e $20 / 30{ }^{\circ} \mathrm{C}$ (no escuro) e então armazenados por $1,10,20,30$ e 40 dias ( 40 dias somente para $4{ }^{\circ} \mathrm{C}$ e $25^{\circ} \mathrm{C}$ ). Os testes de germinação foram conduzidos a $25^{\circ} \mathrm{C}$ e $20 / 30^{\circ} \mathrm{C}$. Os aquênios que não foram embebidos apresentaram sensibilidade à luz durante a germinação. O conteúdo alto de água durante o armazenamento não afetou a resposta à luz dos aquênios durante a germinação, mas o conteúdo alto de água em temperaturas de armazenamento de $25^{\circ} \mathrm{C}$ e $20 / 30^{\circ} \mathrm{C}$ tiveram efeito deletério na longevidade dos mesmos. As temperaturas alternadas durante a germinação não alteraram a resposta à luz de aquênios recém coletados em Itirapina não embebidos, mas alteraram no caso de aquênios embebidos armazenados a $4{ }^{\circ} \mathrm{C}$ no escuro. Temperaturas alternadas durante o armazenamento de aquênios com baixo conteúdo de água não alteraram o fotoblastismo dos mesmos quando a germinação foi realizada a $25^{\circ} \mathrm{C}$. Temperaturas alternadas durante o armazenamento de aquênios com conteúdo de água alto seguidas de temperaturas alternadas durante a germinação alteraram a sensibilidade à luz dos aquênios de Bidens gardneri.

Key words - Cerrado, light sensitivity, storage, moisture content, temperature

\section{Introduction}

In recent decades $87 \%$ of the cerrado areas of the state of São Paulo, Brazil, had been destroyed due to an official encouraging policy towards sugar cane cultivation and timber and wood species plantation (Kronka 1998). Studies on the storage and viability of seeds of cerrado species are very important to

1. Instituto de Botânica, Caixa Postal 4005, 01061-970 São Paulo, SP, Brazil.

2. Research-fellow CNPq, Brazil.

3. Corresponding author: 1zaidan@smtp-gw.ibot.sp.gov.br preserve representatives of this unique vegetation in the few remaining areas.

A common herb of the cerrados in the state of São Paulo which produces ornamental flowers is Bidens gardneri (Asteraceae). This species has been studied for nutrient growth requirements (Felippe \& Dale 1990), flowering induction (Klein et al. 1992) and relations between controlled nutrient conditions and photoperiod for vegetative growth (Klein et al. 1996). Felippe (1990) showed that the species presents light sensitivity when germination is studied at $25^{\circ} \mathrm{C}$; with a long storage period in dry conditions at $4{ }^{\circ} \mathrm{C}$ (up to 14 months) the achenes lose their light sensitivity and readily germinate in darkness. Lon- 
gevity of achenes stored at $4{ }^{\circ} \mathrm{C}$ lasted for a long time; when stored for up to eight years $6 \%$ of the achenes did germinate (Sassaki et al. 1999b). B. gardneri presents heteroblastism, producing long and short achenes; germination in light was high when long achenes were used and very low with short achenes (Felippe 1990).

Sassaki et al. (1999a) showed that the achenes buried in the soil for one month could germinate in darkness. During this storage period the achenes were under the influence of alternating temperatures and showed a high moisture content. The objective of the present study is to relate moisture content and alternating temperatures to the loss of light sensitivity in achenes of Bidens gardneri, but several other aspects were considered here as for example the effect of light during storage, the size of achenes and temperature during storage in the germination in light.

\section{Material and methods}

Ripe achenes (seeds) were collected from several hundred plants of Bidens gardneri Baker in 1997 and 1998 (from now called 1998A) in the cerrado at Itirapina ( $22^{\circ} 51^{\prime} \mathrm{S}$ and $47^{\circ} 52^{\prime} \mathrm{W}$ ), state of São Paulo, Brazil. One experiment was carried out with achenes collected in 1998 (from now called 1998B) in the cerrado of Moji Guaçu ( $22^{\circ} 18^{\prime}$ S and $47^{\circ} 11^{\prime} \mathrm{W}$ ), state of São Paulo, Brazil. B. gardneri population of Itirapina is located in a very disturbed area while the Moji Guaçu population in a preserved area of cerrado. In general, changes in viability and light sensitivity during storage were followed in achenes of median sizes ( 9 and $10 \mathrm{~mm}$ ), but 5-6 $\mathrm{mm}$ and $12-13 \mathrm{~mm}$ long achenes were used in one experiment (see Sassaki et al. 1999a).

The newly-collected achenes were kept at $25^{\circ} \mathrm{C}$ for three days in a bench in the laboratory and then stored in closed glass bottles. The storage conditions of the achenes varied in each experiment. Moisture content and imbibition were determined according to Sassaki et al. (1999a). Moisture content (\%) of the achenes was measured in three replications of 20 achenes. Imbibition rate was calculated in achenes collected in Itirapina (1998A), using five replications of 20 achenes. The imbibition experiment was carried out with newly collected (1998A) achenes in three temperature regimes: $4{ }^{\circ} \mathrm{C}, 25^{\circ} \mathrm{C}$ and $20 / 30{ }^{\circ} \mathrm{C}$ in constant white light. Germination tests were conducted in incubators (temperature varying $\pm 2{ }^{\circ} \mathrm{C}$ ) at $25{ }^{\circ} \mathrm{C}$ and at $20 / 30{ }^{\circ} \mathrm{C}$, depending on the experiment, in $9 \mathrm{~cm}$ diameter Petri dishes on moistened filter paper (three replications of 30 seeds) in darkness or in white fluorescent light at $437 \mu \mathrm{W} \cdot \mathrm{cm}^{-2} . \mathrm{s}^{-1}$ at Petri dish level (Ruggiero $\&$ Zaidan 1997). Darkness was obtained by enclosing the Petri dishes in two black plastic bags and seeds were examined under a green safe light (Labouriau \& Costa 1976). Final germination percentages were determined after 30 days, and the protrusion of the radicle was the criterion of germination.
In the first experiment, newly-collected achenes of 1997 harvest were imbibed at $25^{\circ} \mathrm{C}$ for $1 \mathrm{~h}$ (partially imbibed) and $24 \mathrm{~h}$ (totally imbibed) and after the excess water was removed they were stored at $4{ }^{\circ} \mathrm{C}$ in darkness for 10 and 35 days; dry achenes were stored at the same conditions. The moisture content was determined after 10 and 35 days storage. Germination was carried out in darkness and light at $25^{\circ} \mathrm{C}$. A second experiment was also carried out with achenes of 1997 . The achenes were stored dry (not imbibed) in darkness at $4{ }^{\circ} \mathrm{C}, 20 / 30{ }^{\circ} \mathrm{C}(12 / 12$ daily thermoperiods) or $25{ }^{\circ} \mathrm{C}$. Achenes were imbibed for $24 \mathrm{~h}$ either at $4{ }^{\circ} \mathrm{C}$ and $25{ }^{\circ} \mathrm{C}$ (in darkness) and after the excess water was removed they were stored for $1,10,20,30$ and 40 days or at $20 / 30{ }^{\circ} \mathrm{C}$ (in darkness) and stored for 1, 10, 20 and 30 days. Germination was carried out at $25^{\circ} \mathrm{C}$ in light.

The 1998A newly-collected achenes were used in the following experiments. The tetrazolium test (Delouche et al. 1962) was applied in the $1998 \mathrm{~A}$ achenes stored dry and imbibed at $4{ }^{\circ} \mathrm{C}$, $25{ }^{\circ} \mathrm{C}$ and $20 / 30{ }^{\circ} \mathrm{C}$ for 10 and 30 days. The test was carried out at $25{ }^{\circ} \mathrm{C}$ in darkness during $72 \mathrm{~h}$ using three replications of 30 achenes. The moisture content was determined in achenes stored dry and imbibed at $4{ }^{\circ} \mathrm{C}, 25^{\circ} \mathrm{C}$ and $20 / 30^{\circ} \mathrm{C}$ for 1,10 and 30 days. The effect of light during storage was also studied. The achenes were stored dry in darkness and imbibed (50\% moisture content) in darkness and white light for 10 and 20 days at $4{ }^{\circ} \mathrm{C}, 25^{\circ} \mathrm{C}$ and $20 / 30{ }^{\circ} \mathrm{C}$; germination was carried out at $25^{\circ} \mathrm{C}$ in light. In one experiment with storage at $20 / 30^{\circ} \mathrm{C}$, very short (5-6 mm long) and very long $(12-13 \mathrm{~mm})$ dry achenes were stored for 10 days and imbibed achenes stored for 10,20 and 30 days; germination was carried out at $25^{\circ} \mathrm{C}$ in light and darkness. In the last experiment with this particular harvest achenes were stored dry or imbibed at $4{ }^{\circ} \mathrm{C}, 25^{\circ} \mathrm{C}$ and $20 / 30^{\circ} \mathrm{C}$ for 1,10 and 30 days and the germination was carried out in light and in darkness at $25^{\circ} \mathrm{C}$ and $20 / 30{ }^{\circ} \mathrm{C}$.

The achenes from the 1998B harvest were used in just one experiment. In the experiment with this particular harvest achenes were stored dry or imbibed for one day and then stored for one day at $4{ }^{\circ} \mathrm{C}, 25^{\circ} \mathrm{C}$ and $20 / 30^{\circ} \mathrm{C}$; the germination was carried out in light and in darkness at $25{ }^{\circ} \mathrm{C}$ and $20 / 30{ }^{\circ} \mathrm{C}$.

The germination data were subjected to angular transformation before different treatments were compared by analysis of variance or Student's test (Snedecor 1962).

\section{Results and Discussion}

Storage period and temperature during germination are some of the factors that can change the light requirements of photoblastic seeds (Wareing \& Phillips 1978). The behaviour of the achenes of Bidens gardneri to light was changed when stored in soil for one month (Sassaki et al. 1999a). These achenes buried in the soil presented a moisture content of $c a$. $50 \%$ while the ones stored dry in glass bottles in darkness at $4{ }^{\circ} \mathrm{C}$ had a moisture content of $10 \%$; the achenes stored at $4{ }^{\circ} \mathrm{C}$ were light sensitive during germination while in those stored for one month in the soil the germination was the same both in light 
and in darkness (Sassaki et al. 1999a). Thus one possibility was that the change in light sensitivity behaviour could be caused by the high moisture content of the seeds.

According to Milberg et al. (1996) when the aim of the experiment is to explain a physiological process or response, the inclusion of heavy and light seeds contributes to increase the variation of the data, thereby confounding interpretation of the results. To test the possible relationship between light sensitivity and high moisture content of the achenes, only seeds of median size, 9 and $10 \mathrm{~mm}$, were used. Sassaki et al. (1999a) have shown that the achenes were fully imbibed after five hours from the beginning of the imbibition tests. Achenes of 1997 harvest were imbibed at $25^{\circ} \mathrm{C}$ for $1 \mathrm{~h}$ (partially imbibed) and $24 \mathrm{~h}$ (totally imbibed) and stored in closed bottles at $4{ }^{\circ} \mathrm{C}$ in darkness for 10 and 35 days; dry achenes were stored at the same conditions. The moisture content was determined immediately after imbibition and after 10 and 35 days storage: dry achenes presented a moisture content of $10 \%$ independent of period of storage. The moisture content of achenes imbibed for $1 \mathrm{~h}$ was $25 \%$ immediately after imbibition and when stored for either 10 or 35 days; however, when imbibition lasted for $24 \mathrm{~h}$, storage during either 10 or 35 days led to $47 \%$ moisture content. Thus achenes imbibed for $24 \mathrm{~h}$ and kept at $4{ }^{\circ} \mathrm{C}$ in darkness for 10 and 35 days presented a moisture content very similar to that of achenes stored in soil for more than one month (Sassaki et al. 1999a). The results of the germination tests of these treatments are shown in figure 1 . The achenes not previously imbibed (dry) showed sensitivity to light after 10 and 35 days storage at $4{ }^{\circ} \mathrm{C}$ (figure 1A,B). The light sensitivity was not altered by previously imbibing the achenes for $1 \mathrm{~h}$ or $24 \mathrm{~h}$ and storing them for 10 or 35 days (figure 1C-F). Thus the high moisture content of the achenes buried in the soil for one month should not be responsible for changing the seed requirement to light reported by Sassaki et al. (1999a).

A second possibility to explain why the achenes lose their light sensitivity when stored in soil is soil temperature. Ortolani \& Pinto (1972) reported alternating temperatures in a cerrado soil in the State of São Paulo at 5 or $10 \mathrm{~cm}$ deep $\left(c a .22^{\circ} \mathrm{C}\right.$ at $8.00 \mathrm{~h}$ and $35^{\circ} \mathrm{C}$ at $16.00 \mathrm{~h}$ ) but the temperatures were nearly

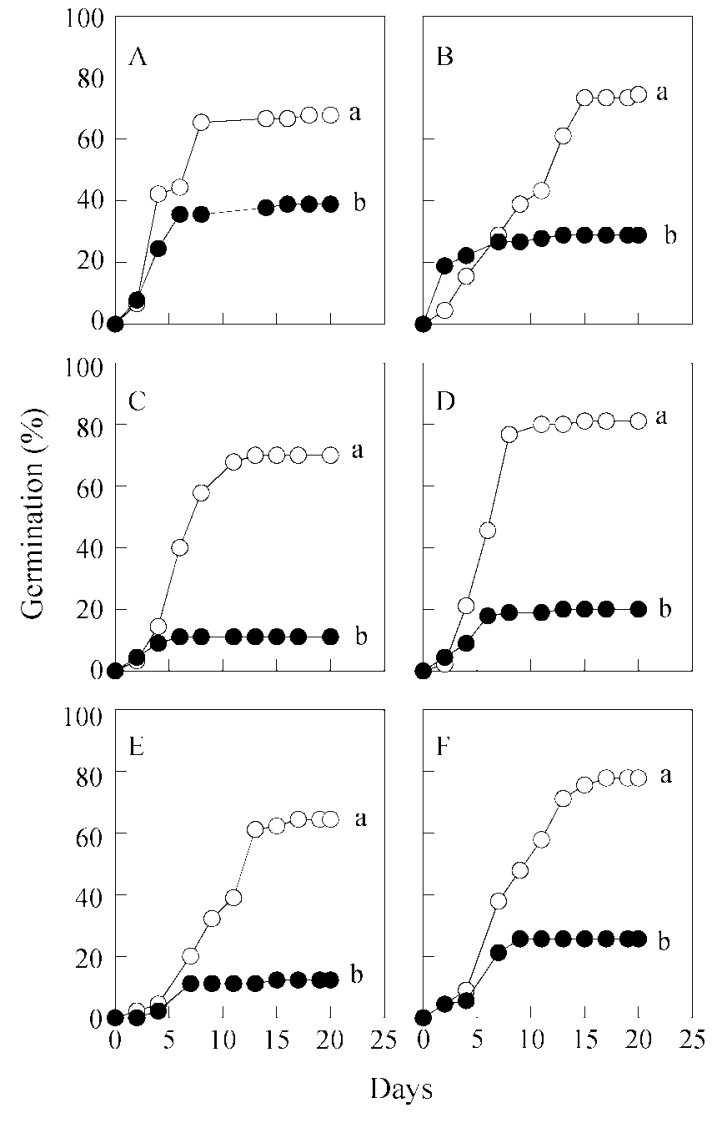

Figure 1. Germination at $25{ }^{\circ} \mathrm{C}$ in light (open symbols) and in darkness (closed symbols) of newly collected (harvest 1997) achenes of B. gardneri stored (dry) at $4{ }^{\circ} \mathrm{C}$ in darkness for 10 (A) and 35 days (B), control treatment; artificially imbibed for $1 \mathrm{~h}$ and stored at $4{ }^{\circ} \mathrm{C}$ in darkness for 10 (C) and 35 days (D); artificially imbibed for $24 \mathrm{~h}$ and stored at $4{ }^{\circ} \mathrm{C}$ in darkness for 10 (E) and 35 days $(\mathrm{F})$. Small letters compare germination in light and darkness in each treatment.

constant at $20 \mathrm{~cm}$ deep $\left(\mathrm{ca} .25^{\circ} \mathrm{C}\right)$. In the experiments conducted by Sassaki et al. (1999a) the achenes were stored at $10 \mathrm{~cm}$ deep in the cerrado or in the forest. The achenes of $B$. gardneri are usually stored dry in closed bottles, in dark, at $4{ }^{\circ} \mathrm{C}$ (Felippe 1990). Taking all this information into account, in this work dry and imbibed achenes were stored at the temperatures of $4{ }^{\circ} \mathrm{C}, 25{ }^{\circ} \mathrm{C}$ and $20 / 30^{\circ} \mathrm{C}$.

In one experiment achenes (1998A) were stored dry or imbibed at $4{ }^{\circ} \mathrm{C}, 25^{\circ} \mathrm{C}$ and $20 / 30^{\circ} \mathrm{C}$ and stored for 1,10 and 30 days and the germination was carried out in light and in darkness at $25^{\circ} \mathrm{C}$ and $20 / 30^{\circ} \mathrm{C}$. 
The germination results are presented in table 1 . Achenes imbibed at $25{ }^{\circ} \mathrm{C}$ and $20 / 30{ }^{\circ} \mathrm{C}$ and stored for 30 days deteriorated during storage and could not be used for germination (dead achenes). The majority of the achenes imbibed at $25^{\circ} \mathrm{C}$ and $20 / 30^{\circ} \mathrm{C}$ and stored for 10 days deteriorated during storage; the number of viable achenes was not enough to prepare three replicates, so just one replicate was used for germination and these treatments could not be submitted to statistical analysis (in table 1 they are marked with $*$ ). Temperature and period of storage had no effect upon the light sensitivity of the dry achenes when the germination was tested at $25{ }^{\circ} \mathrm{C}$ and $20 / 30^{\circ} \mathrm{C}$ : germination was significantly higher in light than in darkness, with one exception in which germination in the dark at $20 / 30^{\circ} \mathrm{C}$ was significantly

Table 1. Germination (on day 30 ) at $25{ }^{\circ} \mathrm{C}$ and $20 / 30{ }^{\circ} \mathrm{C}$ in light and darkness of newly collected achenes of B. gardneri (1998A) and stored dry (10\% moisture content) and imbibed (see table 3 for moisture content) at $4{ }^{\circ} \mathrm{C}, 25{ }^{\circ} \mathrm{C}$ and $20 / 30{ }^{\circ} \mathrm{C}$ in darkness for 1,10 and 30 days.

\begin{tabular}{|c|c|c|c|c|c|}
\hline \multirow{3}{*}{$\begin{array}{l}\text { Storage } \\
\text { condition }\end{array}$} & \multirow{3}{*}{$\begin{array}{l}\text { Storage } \\
\text { period } \\
\text { (days) }\end{array}$} & \multicolumn{4}{|c|}{ Germination (\%) } \\
\hline & & \multicolumn{2}{|c|}{$25^{\circ} \mathrm{C}$} & \multicolumn{2}{|c|}{$20 / 30{ }^{\circ} \mathrm{C}$} \\
\hline & & light & darkness & light & darkness \\
\hline \multirow{3}{*}{$\begin{array}{l}4^{\circ} \mathrm{C} \\
\text { dry }\end{array}$} & 1 & $96.6 \mathrm{a}$ & $13.3 \mathrm{bD}$ & $90.0 \mathrm{a}$ & $14.4 \mathrm{bD}$ \\
\hline & 10 & $62.2 \mathrm{a}$ & $5.5 \mathrm{bE}$ & $68.8 \mathrm{a}$ & $12.2 \mathrm{bD}$ \\
\hline & 30 & $80.0 \mathrm{a}$ & $8.8 \mathrm{bE}$ & $97.7 \mathrm{a}$ & $16.6 \mathrm{bD}$ \\
\hline \multirow{3}{*}{$\begin{array}{l}4^{\circ} \mathrm{C} \\
\text { imbibed }\end{array}$} & 1 & $84.4 \mathrm{a}$ & $16.6 \mathrm{bD}$ & $94.4 \mathrm{a}$ & $26.6 \mathrm{bC}$ \\
\hline & 10 & $77.7 \mathrm{a}$ & $16.6 \mathrm{bD}$ & $96.6 \mathrm{a}$ & $16.6 \mathrm{bD}$ \\
\hline & 30 & $78.8 \mathrm{a}$ & $16.6 \mathrm{bD}$ & $92.2 \mathrm{a}$ & $33.3 \mathrm{bB}$ \\
\hline \multirow{3}{*}{$\begin{array}{l}25^{\circ} \mathrm{C} \\
\text { dry }\end{array}$} & 1 & $75.5 \mathrm{a}$ & $20.0 \mathrm{bD}$ & $90.0 \mathrm{a}$ & $14.4 \mathrm{bD}$ \\
\hline & 10 & $91.1 \mathrm{a}$ & $22.2 \mathrm{bD}$ & $98.8 \mathrm{a}$ & $21.1 \mathrm{bD}$ \\
\hline & 30 & $85.5 \mathrm{a}$ & $20.0 \mathrm{aD}$ & $90.0 \mathrm{a}$ & $22.2 \mathrm{bD}$ \\
\hline \multirow{2}{*}{$\begin{array}{l}25^{\circ} \mathrm{C} \\
\text { imbibed }\end{array}$} & 1 & $87.7 \mathrm{a}$ & $28.8 \mathrm{bC}$ & $97.7 \mathrm{a}$ & $27.7 \mathrm{bC}$ \\
\hline & 10 & $100.0^{*}$ & $20.0^{*}$ & $100.0^{*}$ & $27.0^{*}$ \\
\hline \multirow{3}{*}{$\begin{array}{l}20 / 30{ }^{\circ} \mathrm{C} \\
\text { dry }\end{array}$} & 1 & $83.3 \mathrm{a}$ & $10.0 \mathrm{bD}$ & $100.0 \mathrm{a}$ & $13.3 \mathrm{bD}$ \\
\hline & 10 & $74.4 \mathrm{a}$ & $20.0 \mathrm{bD}$ & $98.8 \mathrm{a}$ & $11.1 \mathrm{bD}$ \\
\hline & 30 & $78.8 \mathrm{a}$ & $15.5 \mathrm{bD}$ & $87.7 \mathrm{a}$ & $32.2 \mathrm{bB}$ \\
\hline \multirow{2}{*}{$\begin{array}{l}20 / 30^{\circ} \mathrm{C} \\
\text { imbibed }\end{array}$} & 1 & $92.2 \mathrm{a}$ & $25.5 \mathrm{bD}$ & $100.0 \mathrm{a}$ & $68.8 \mathrm{bA}$ \\
\hline & 10 & $100.0 *$ & $100.0^{*}$ & $100.0 *$ & $92.0 *$ \\
\hline
\end{tabular}

*: one replicate only; no statistical analysis in these cases Small letters: Student's test between light and darkness in each treatment. Capital letters: values of germination in darkness analysed by ANOVA, different letters mean significant differences. $\mathrm{F}_{5} \%$ not significant for all values of germination in light. higher than at $25{ }^{\circ} \mathrm{C}$, this including achenes stored dry at $20 / 30{ }^{\circ} \mathrm{C}$ for 30 days. Thus the use of alternating temperature during the germination test does not affect the light sensitivity of newly collected achenes with low moisture content. In relation to the achenes stored imbibed (around 50\% moisture content) the light sensitivity was lost only when the imbibed achenes were stored at $20 / 30^{\circ} \mathrm{C}$ for 10 days and the germination tests were carried out both at $25^{\circ} \mathrm{C}$ and at $20 / 30{ }^{\circ} \mathrm{C}$ (table 1 ). But as mentioned above no statistical analysis could be applied in these cases. When the achenes were stored imbibed at $20 / 30{ }^{\circ} \mathrm{C}$ for one day and the germination test was carried out also at $20 / 30{ }^{\circ} \mathrm{C}$ there was a promotion of germination in darkness (a value of $68.8 \%$ ), a value statistically different from all other values obtained during germination in darkness (see last column in table 1). However, achenes of B. gardneri collected in Moji Guaçu (1998B) showed a different behaviour: the dry and the imbibed achenes stored at $4{ }^{\circ} \mathrm{C}, 25{ }^{\circ} \mathrm{C}$ and $20 / 30^{\circ} \mathrm{C}$ lost their light sensitivity when germination was carried out at $20 / 30^{\circ} \mathrm{C}$ (table 2): thus for the 1998B achenes the important was the temperature during germination instead of the storage temperature. Pandley \& Dubey (1988) have shown differences in the sensitivity to light and alternate temperatures in achenes collected from different populations in India. These authors concluded that

Table 2. Germination (on day 30 ) at $25^{\circ} \mathrm{C}$ and $20 / 30^{\circ} \mathrm{C}$ in light and darkness of achenes of B. gardneri (1998B) collected in Moji Guaçu, stored in darkness dry and imbibed for one day and kept for one day at $4{ }^{\circ} \mathrm{C}, 25^{\circ} \mathrm{C}$ and $20 / 30{ }^{\circ} \mathrm{C}$.

\begin{tabular}{|c|c|c|c|c|c|}
\hline & \multirow{3}{*}{$\begin{array}{c}\text { Storage } \\
\text { tempe- } \\
\text { rature }\end{array}$} & \multicolumn{4}{|c|}{ Germination (\%) } \\
\hline & & \multicolumn{2}{|c|}{$25^{\circ} \mathrm{C}$} & \multicolumn{2}{|c|}{$20 / 30^{\circ} \mathrm{C}$} \\
\hline & & light & darkness & light & darkness \\
\hline \multirow{3}{*}{ dry } & $4{ }^{\circ} \mathrm{C}$ & $55.5 \mathrm{a}$ & $23.3 \mathrm{bC}$ & $65.5 \mathrm{a}$ & $43.3 \mathrm{aA}$ \\
\hline & $25^{\circ} \mathrm{C}$ & $64.4 \mathrm{a}$ & $18.8 \mathrm{bC}$ & $81.1 \mathrm{a}$ & $32.2 \mathrm{bAB}$ \\
\hline & $20 / 30^{\circ} \mathrm{C}$ & $77.7 \mathrm{a}$ & $23.3 \mathrm{bC}$ & $67.7 \mathrm{a}$ & $51.1 \mathrm{aA}$ \\
\hline \multirow{3}{*}{ imbibed } & $4^{\circ} \mathrm{C}$ & $72.2 \mathrm{a}$ & $14.4 \mathrm{bC}$ & $75.5 \mathrm{a}$ & $46.6 \mathrm{aA}$ \\
\hline & $25^{\circ} \mathrm{C}$ & $75.5 \mathrm{a}$ & $12.2 \mathrm{bC}$ & $61.1 \mathrm{a}$ & $51.1 \mathrm{aA}$ \\
\hline & $20 / 30{ }^{\circ} \mathrm{C}$ & $73.3 \mathrm{a}$ & $21.1 \mathrm{bC}$ & $61.1 \mathrm{a}$ & $58.9 \mathrm{aA}$ \\
\hline
\end{tabular}

Small letters: Student's test between light and darkness in each treatment. Capital letters: values of germination in darkness analysed by ANOVA, different letters mean significant differences. $\mathrm{F}_{5} \%$ not significant for all values of germination in light. 
this behaviour was due to the effects of different disturbance levels and environmental conditions in the distinct areas. However these conclusions can not be used for the present study as only parts of one population in Itirapina and one in Moji Guaçu were tested. To make the same assumptions a more detailed research studying several populations from these two areas is necessary.

An imbibition experiment was carried out with newly collected (1998A) achenes in the three temperature regimes used here: $4^{\circ} \mathrm{C}, 25^{\circ} \mathrm{C}$ and $20 / 30{ }^{\circ} \mathrm{C}$ in constant white light. It was important to find out if these three temperatures could affect the imbibition of the achenes. The imbibition proceeded for five hours when $60 \%$ imbibition was reached by the achenes in all the temperature treatments. No statistical difference (ANOVA) between imbibition at these three temperature regimes was detected (data not shown). Thus if these temperatures had an effect upon response to light during germination this was not because of differences in imbibition of the achenes. Storage temperature had a very strong effect on the germination in light of achenes stored in darkness with high $(45 \%)$ moisture content as can be seen in table 3. Storage temperature in darkness had no effect upon germination in light in low moisture $(10 \%)$ content achenes stored for 1, 10 and 30 days.

Table 3. Germination (on day 30) at $25{ }^{\circ} \mathrm{C}$ in light of achenes of B. gardneri collected in 1997 stored dry $(10 \% \mathrm{mc})$ or imbibed for $24 \mathrm{~h}(45 \% \mathrm{mc})$ at $4{ }^{\circ} \mathrm{C}, 25^{\circ} \mathrm{C}$ and $20 / 30^{\circ} \mathrm{C}$ in darkness for 1,10 , 30 and 40 days. Small letters compare germination between control and imbibed achenes in each storage condition.

\begin{tabular}{|c|c|c|c|c|}
\hline \multirow{3}{*}{$\begin{array}{l}\text { Moisture content (mc) } \\
\text { (stored achenes) }\end{array}$} & \multicolumn{4}{|c|}{ Germination $(\%)$} \\
\hline & \multicolumn{4}{|c|}{ storage period (days) } \\
\hline & 1 & 10 & 30 & 40 \\
\hline & \multicolumn{4}{|c|}{ storage temperature $4{ }^{\circ} \mathrm{C}$} \\
\hline dry $(10 \% \mathrm{mc})$ & $93.2 \mathrm{a}$ & $88.8 \mathrm{a}$ & $93.3 \mathrm{a}$ & $92.2 \mathrm{a}$ \\
\hline \multirow[t]{2}{*}{ imbibed ( $45 \% \mathrm{mc})$} & $87.7 \mathrm{a}$ & $91.1 \mathrm{a}$ & $85.5 \mathrm{a}$ & $38.8 \mathrm{~b}$ \\
\hline & \multicolumn{4}{|c|}{ storage temperature $25^{\circ} \mathrm{C}$} \\
\hline dry $(10 \% \mathrm{mc})$ & $93.3 \mathrm{a}$ & $83.3 \mathrm{a}$ & $88.8 \mathrm{a}$ & $91.1 \mathrm{a}$ \\
\hline \multirow[t]{2}{*}{ imbibed $(45 \% \mathrm{mc})$} & $86.6 \mathrm{a}$ & $47.7 \mathrm{~b}$ & $11.1 \mathrm{~b}$ & $1.1 \mathrm{~b}$ \\
\hline & \multicolumn{4}{|c|}{ storage temperature $20 / 30^{\circ} \mathrm{C}$} \\
\hline dry $(10 \% \mathrm{mc})$ & $100.0 \mathrm{a}$ & $98.8 \mathrm{a}$ & $87.7 \mathrm{a}$ & - \\
\hline imbibed $(45 \% \mathrm{mc})$ & $98.8 \mathrm{a}$ & $41.0 \mathrm{~b}$ & $0.0 \mathrm{~b}$ & - \\
\hline
\end{tabular}

$-:$ not tested
No effect was observed even up to day 40 of storage at $4{ }^{\circ} \mathrm{C}$ and $25{ }^{\circ} \mathrm{C}$ (table 3 ). With the imbibed achenes, however, germination was strongly reduced when the achenes were stored at $4{ }^{\circ} \mathrm{C}$ for at least 40 days (but not before). The reduction in germination could be seen already in imbibed achenes stored for 10 days when the temperature during storage was $25^{\circ} \mathrm{C}$ or $20 / 30{ }^{\circ} \mathrm{C}$ (table 3 ). Also a large number of the imbibed achenes died during storage at $25{ }^{\circ} \mathrm{C}$ and $20 / 30{ }^{\circ} \mathrm{C}$ for periods longer than 10 days.

To find out if the achenes that did not germinate shown in table 3 were dead, the tetrazolium test was applied in the achenes stored dry and imbibed at $4{ }^{\circ} \mathrm{C}, 25{ }^{\circ} \mathrm{C}$ and $20 / 30{ }^{\circ} \mathrm{C}$ for 10 and 30 days. The results can be seen in table 4: there was a strong reduction in the reaction to the tetrazolium in imbibed achenes stored for 10 and 30 days at $25^{\circ} \mathrm{C}$ and $20 / 30{ }^{\circ} \mathrm{C}$; after 30 days storage the majority of the achenes must have been dead. This effect was not observed in imbibed achenes stored at $4{ }^{\circ} \mathrm{C}$ and in all dry achenes stored at $4{ }^{\circ} \mathrm{C}, 25^{\circ} \mathrm{C}$ and $20 / 30{ }^{\circ} \mathrm{C}$ for 10 and 30 days. The moisture content of newly collected achenes is presented in table 5. The data show small differences in the moisture content of achenes imbibed for 1,10 or 30 days in the three temperature regimes tested. Taking into account tables 3 and 5, high moisture content of the achenes and higher temperatures during storage $\left(25^{\circ} \mathrm{C}\right.$ or $20 / 30{ }^{\circ} \mathrm{C}$ ) seem to be responsible for the death of the achenes of B. gardneri. Low temperature $\left(4{ }^{\circ} \mathrm{C}\right)$ during storage of achenes with high moisture content delays the death of the achenes when compared to higher temperatures during storage (table 3 ).

It seems that light is also important for seed viability during storage of imbibed achenes at controlled temperatures, as can be seen in figure 2. The presence of light during storage did not change viability when the imbibed achenes were stored at $4{ }^{\circ} \mathrm{C}$

Table 4. Results of the tetrazolium test of dry and imbibed achenes of B. gardneri (1998A) stored at $4{ }^{\circ} \mathrm{C}, 25^{\circ} \mathrm{C}$ and $20 / 30{ }^{\circ} \mathrm{C}$ in darkness for 10 and 30 days.

\begin{tabular}{|c|c|c|c|c|c|c|}
\hline \multirow{3}{*}{$\begin{array}{l}\text { Storage } \\
\text { (days) }\end{array}$} & \multicolumn{6}{|c|}{ red-stained embryos $(\%)$} \\
\hline & \multicolumn{2}{|c|}{$4{ }^{\circ} \mathrm{C}$} & \multicolumn{2}{|c|}{$25^{\circ} \mathrm{C}$} & \multicolumn{2}{|c|}{$20 / 30{ }^{\circ} \mathrm{C}$} \\
\hline & dry & imbibed & dry & imbibed & dry & imbibed \\
\hline 10 & 81.0 & 85.5 & 92.2 & 39.9 & 93.3 & 49.9 \\
\hline 30 & 79.9 & 87.7 & 78.8 & 6.6 & 82.2 & 2.2 \\
\hline
\end{tabular}


Table 5. Moisture content (\%) of dry and imbibed achenes of $B$. gardneri (1998A) stored at $4{ }^{\circ} \mathrm{C}, 25^{\circ} \mathrm{C}$ and $20 / 30{ }^{\circ} \mathrm{C}$ for 1,10 and 30 days.

\begin{tabular}{|c|c|c|c|c|c|c|}
\hline \multirow{3}{*}{$\begin{array}{l}\text { Storage } \\
\text { (days) }\end{array}$} & \multicolumn{6}{|c|}{ moisture content $(\%)$} \\
\hline & \multicolumn{2}{|c|}{$4{ }^{\circ} \mathrm{C}$} & \multicolumn{2}{|c|}{$25^{\circ} \mathrm{C}$} & \multicolumn{2}{|c|}{$20 / 30^{\circ} \mathrm{C}$} \\
\hline & dry & imbibed & dry & imbibed & dry & imbibed \\
\hline 1 & 10.6 & 46.1 & 10.6 & 49.0 & 10.9 & 48.6 \\
\hline 10 & 10.7 & 49.6 & 10.7 & 50.6 & 10.7 & 52.0 \\
\hline 30 & 10.9 & 49.0 & 10.7 & 56.8 & 10.6 & 58.4 \\
\hline
\end{tabular}

(figures 2A, B). But at $25{ }^{\circ} \mathrm{C}$ storage of imbibed achenes has a inhibitory effect in germination: achenes imbibed and stored for 10 days in light at $25^{\circ} \mathrm{C}$ showed the same final germination as the dry achenes (figure $2 \mathrm{C}$ ) and a strong reduction of germination occurs when achenes are stored for 20 days (figure 2D); in imbibed achenes stored in darkness for 10 days germination was very low (figure $2 \mathrm{C}$ ) and when stored for 20 days germination was nihil (figure 2D).

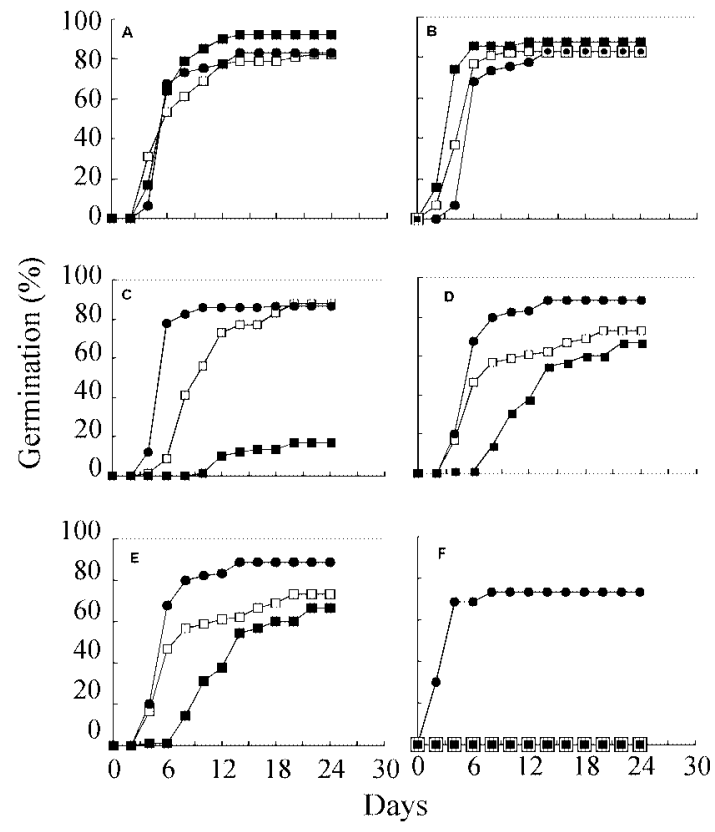

Figure 2. Germination in light at $25{ }^{\circ} \mathrm{C}$ of achenes of $B$. gardneri (harvest 1998A) stored dry (10\% moisture content) in darkness and stored imbibed (50\% moisture content) in darkness and in white light for 10 and 20 days at $4{ }^{\circ} \mathrm{C}(\mathrm{A}, \mathrm{B})$, at $25^{\circ} \mathrm{C}(\mathrm{C}, \mathrm{D})$ and at $20 / 30{ }^{\circ} \mathrm{C}$ (E, F). Closed circles: dry achenes; open squares: imbibed achenes stored in light; closed squares: imbibed achenes stored in darkness.
During storage in light at $25{ }^{\circ} \mathrm{C}$ some imbibed achenes germinated: $45 \%$ of the achenes germinated during the 10 days storage period and $46 \%$ during the 20 days storage period (although germination only occurred during the first 10 days). When the imbibed achenes were stored at $20 / 30{ }^{\circ} \mathrm{C}$ (figures $2 \mathrm{E}, \mathrm{F}$ ) germination was inhibited with storage for 20 days. Figure $2 \mathrm{E}$ shows a non-significant reduction in germination for imbibed achenes stored at $20 / 30{ }^{\circ} \mathrm{C}$ (in relation do dry achenes) in light and in darkness for 10 days; no germination occurred in achenes stored for 20 days, in light and darkness (figure $2 \mathrm{~F}$ ).

The viability of median sized achenes of $B$. gardneri is reduced when they are stored at $20 / 30{ }^{\circ} \mathrm{C}$ in darkness with high moisture content for 10 days and longer (see table 3 ). When very short and very long achenes (1998A) were stored imbibed at $20 / 30{ }^{\circ} \mathrm{C}$ for 10,20 and 30 days dead achenes were only found among the short achenes stored for 30 days ( $41.2 \%$ were alive); in relation to long achenes $25 \%$ of them were alive after storage for 20 days against only $1.2 \%$ when storage lasted for 30 days. Compared to the dry achenes germination (carried out at $25^{\circ} \mathrm{C}$ ) was reduced in all the imbibed achenes stored for 10 days (table 6); both long and short achenes were sensitive to light (see data for the achenes stored for 10 days). Germination was further reduced when the short achenes were stored for 20 and 30 days and no germination occurred in imbibed long achenes stored for 20 days (table 6). Felippe (1990) has shown that the newly collected short achenes of $B$. gardneri were dormant when compared to the long ones and that with the removal of the seed coat the short achenes did germinate. In the present work it has been shown that the short achenes

Table 6. Germination (on day 30 ) at $25^{\circ} \mathrm{C}$ in light and darkness of short (5-6 mm long) and long (12-13 mm long) achenes of $B$. gardneri (1998A) stored dry and imbibed, at $20 / 30{ }^{\circ} \mathrm{C}$ in darkness for 10,20 and 30 days.

\begin{tabular}{lcccccc}
\hline \multirow{2}{*}{$\begin{array}{l}\text { Storage } \\
\text { conditions }\end{array}$} & \multicolumn{4}{c}{ Germination (\%) } \\
\cline { 3 - 4 } & & \multicolumn{2}{c}{ short achenes } & & \multicolumn{2}{c}{ long achenes } \\
\cline { 3 - 4 } \cline { 6 - 7 } & light & dark & & light & dark \\
\hline \multirow{2}{*}{ dry } & 10 days & 80 & 30 & & 70 & 30 \\
imbibed & 10 days & 28 & 13 & & 20 & 7 \\
& 20 days & 5 & 5 & & 0 & 0 \\
& 30 days & 3 & 0 & & - \\
\hline
\end{tabular}


survive for a longer period of time $(41.2 \%$ of short achenes were alive after storage for 30 days while only $1.2 \%$ of long achenes were alive with the same storage period) than the long ones when artificially imbibed, but no differences could be seen in their germination. No differences in germination between short and long achenes which were not imbibed and stored at $4{ }^{\circ} \mathrm{C}$ were also reported previously (Sassaki et al. 1999a). Differences in germination of short and long achenes have been also shown for Bidens pilosa (Forsyth \& Brown 1982). In Bidens odorata long achenes germinate better and lose their light sensitivity during storage faster than the short ones (Corkidi et al. 1991).

The present results could be resumed as follows: 1. high moisture content does not affect the light sensitivity of the achenes of $B$. gardneri during germination;

2. alternate temperatures during storage of achenes with low moisture content do not change their photoblastim when the achenes were germinated at $25^{\circ} \mathrm{C}$;

3. alternate temperatures during storage of achenes collected in Itirapina with high moisture content followed by alternate temperatures during germination change the light sensitivity of the achenes (this can explain the germination of $B$. gardneri achenes during storage in the soil, as reported by Sassaki et al. 1999a). Also alternate temperatures during storage of achenes, change the light sensitivity of the achenes when germination is carried out at $25{ }^{\circ} \mathrm{C}$. This explains why the intact achenes removed from the soil lose their photoblastism after 1 and 3 months storage as related by Sassaki et al. (1999a);

4. alternate temperatures of $20 / 30{ }^{\circ} \mathrm{C}$ during germination do not change the light sensitivity of achenes collected in Itirapina and stored for short periods of time (up to 30 days) at $4{ }^{\circ} \mathrm{C}$;

5. high moisture content together with storage temperatures of $25^{\circ} \mathrm{C}$ and $20 / 30{ }^{\circ} \mathrm{C}$ have a deleterious effect upon the longevity of the achenes (life span strongly reduced).

Acknowledgements - Are due to Dr Peter E. Gibbs, from St. Andrews University, for revising the English in a draft version.

\section{References}

CORKIDI, L., RINCON, E. \& VAZQUEZ-YANES, C. 1991. Effects of light and temperature on germination of heteromorphic achenes of Bidens odorata (Asteraceae). Canadian Journal of Botany 69:574-579.

DELOUCHE, J.C., STILL, T. W., RASFET, M. \& LIENHARD, M. 1962. The tetrazolium test for seed viability. Mississipi Agricultural Experiment Station Technical Bulletin 51:1-64.

FELIPPE, G.M. 1990. Germinação de Bidens gardneri Baker, uma planta anual dos cerrados. Hoehnea 17:7-11.

FELIPPE, G.M. \& DALE, J.E. 1990. The effects of phosphorus supply on growth of plants from the Brazilian cerrado: experiments with seedlings of the annual weed Bidens gardneri Baker (Compositae) and the tree Qualea grandiflora Mart. (Vochysiaceae). Oecologia 82:81-86.

FORSYTH, C. \& BROWN, N.A.C. 1982. Germination of dimorphic fruits of Bidens pilosa L. New Phytologist 90:151-164.

KLEIN, A.L., ZAIDAN, L.B.P. \& FELIPPE, G.M. 1992. Flowering and heterophylly in Bidens gardneri Baker. Revista brasileira de Botânica 15:139-144.

KLEIN, A.L., ZAIDAN, L.B.P. \& FELIPPE, G.M. 1996. Interaction between soil and photoperiod on development of Bidens gardneri Baker (Asteraceae), a herbaceous species from the Brazilian cerrado. Revista Brasileira de Botânica 19:1-5.

KRONKA, F.J.N. 1998. Áreas de domínio do cerrado no Estado de São Paulo. São Paulo: Secretaria do Meio Ambiente. São Paulo.

LABOURIAU, L.F.G. \& COSTA, J.A.F. 1976. Objetivos e instalações básicas de um laboratório de fisiologia vegetal. Academia Brasileira de Ciências, Rio de Janeiro.

MILBERG, P., ANDERSSON, L., ELFVERSON, C. \& REGNÉR, S. 1996. Germination characteristics of seeds differing in mass. Seed Science Research 6:191-197.

ORTOLANI, A.A. \& PINTO, H.S. 1972. Temperatura do solo. In Elementos de pedologia (A.A. Moniz, ed.). Editora Polígono, São Paulo.

PANDLEY, H.N. \& DUBEY, S.K. 1988. Achene germination of Parthenium hysterophorus L.: effects of light, temperature, provenance and achene size. Weed Research 28:185-190.

RUGGIERO, P.G.C. \& ZAIDAN, L.B.P. 1997. Estudos de desenvolvimento de Viguiera robusta Gardn., uma Asteraceae do cerrado. Revista Brasileira de Botânica 20:1-9.

SASSAKI, R.M., ZAIDAN, L.B.P. \& FELIPPE, G.M. 1999a. Effect of storage of achenes of Bidens gardneri Baker on light sensitivity during germination. Revista Brasileira de Botânica 22:75-81.

SASSAKI, R.M., RONDON, J.N., ZAIDAN, L.B.P. \& FELIPPE, G.M. 1999b. Germination of seeds from herbaceous plants artificially stored in cerrado soil. Revista Brasileira de Biologia 59:271-279.

SNEDECOR, G.W. 1962. Statistical methods. Iowa State University Press, Iowa.

WAREING, P.F. \& PHILLIPS, I.D.J. 1978. The control of growth and differentiation in plants. Pergamon Press, Oxford. 